\title{
Design, Synthesis and Anticancer Activities of Diaryl Urea Derivatives Bearing $N$-Acylhydrazone Moiety
}

\author{
Bei Zhang, ${ }^{a}$ Yanfang Zhao, ${ }^{a}$ Xin Zhai, ${ }^{a}$ Lihui Wang, ${ }^{b}$ Jingyu Yang, ${ }^{b}$ Zehui Tan ${ }^{a}$ and \\ Ping Gong*,a \\ ${ }^{a}$ Key Laboratory of Structure-Based Drug Design \& Discovery, Ministry of Education, School of Pharmaceutical \\ Engineering, Shenyang Pharmaceutical University; and ${ }^{b}$ School of Life Science and Biopharmaceutics, Shenyang \\ Pharmaceutical University; Shenyang, Liaoning 110016, P. R. China.
}

Received April 16, 2012; accepted May 18, 2012

\begin{abstract}
A new series of diaryl urea derivatives bearing $\mathrm{N}$-acylhydrazone moiety were designed and synthesized. All the target compounds were evaluated for their cytotoxic activities in vitro against human lung adenocarcinoma epithelial cell line (A549), human breast cancer cell line (MDA-MB-231) and human leukemia cell line (HL-60) by standard 3-(4,5-dimethylthiazol-2-yl)-2,5-diphenyltetrazolium bromide (MTT) assay. Several compounds (1a, If and $1 \mathrm{~h}$ ) were further evaluated against human embryonic fibroblast, lung-derived cell line (WI38). The pharmacological results indicated that some compounds exhibited promising anticancer activities. In particular, compound $1 \mathrm{f}$ showed the most potent cytotoxicity against the tested three cell lines with IC $_{50}$ values of $0.41 \mu \mathrm{M}, 0.24 \mu \mathrm{M}$ and $0.23 \mu \mathrm{M}$, respectively.
\end{abstract}

Key words diaryl urea; $N$-acylhydrazone; anticancer activity

During the past decade, a large number of multitargeted inhibitors were reported to exhibit anticancer activities with various mechanisms of action as distinct from those cytotoxic drugs and mono-targeted inhibitors. ${ }^{1-4)}$ Some of them have been developed successfully such as sorafenib (Nexavar), sunitinib (Sutent) and lapatinib (Tykerb). Sorafenib (Fig. 1), the first orally bioavailable multitargeted receptor tyrosine kinase inhibitor, has a reasonable enzyme potency against Raf, vascular endothelial growth factor receptor (VEGFR) and platelet derived growth factor receptor (PDGFR) and pathway inhibition in cells $\left(\mathrm{IC}_{50}\right.$ values of $40-1200 \mathrm{~nm}$ depending on the cell line) ${ }^{5-9)}$ It was approved by Food and Drug Administration (FDA) for the treatment of advanced renal cell carcinoma in December 2005 and hepatocellular carcinoma in November in 2007, respectively. ${ }^{10,11)}$

PAC-1 (Fig. 1) is the first small molecular procaspase-3 activator that induces apoptotic death in tumor cell lines and retards tumor growth in vivo. ${ }^{12,13)}$ In an attempt to discover new anticancer agents with multi-targeted molecular mechanisms, we combined the diaryl urea moiety from sorafenib and $\mathrm{N}$-acylhydrazone, the pharmacophore of PAC-1, with a thiazolyl ring (structure 1) or an amide bond (structure 2) as the linker. Thus a series of diaryl urea derivatives bearing $N$ acylhydrazone moiety (Fig. 2) were designed and synthesized. Various substituted ureido-linked phenyl $\left(\mathrm{Ar}^{1}\right)$ and hydrazonelinked phenyl $\left(\mathrm{Ar}^{2}\right)$ groups were introduced to explore the influence of electronic and steric effects on the anticancer activity. Since only with the hydroxyl group on the phenyl ring $\mathrm{Ar}^{2}$ did the PAC-1 derivatives display antitumor activity in vitro, ${ }^{12)}$ 2-hydroxyl substitution was retained for the phenyl ring $\mathrm{Ar}^{2}$. Four- and 5-benzoxyl groups were respectively introduced to the phenyl ring $\mathrm{Ar}^{2}$ to investigate the effect of the extension of the hydrophobic region. Furthermore, the phenyl group at $\mathrm{Ar}^{2}$ was replaced with a substituted chromenonyl group which was often associated with a variety of biological activities to explore whether such a replacement would bring a significant rise in anticancer activity.

\section{Results and Discussion}

Chemistry The synthetic route of target compounds $\mathbf{1 a}-\mathbf{i}$ is described in Chart 1 . The commercially available 4-aminobezonitrile reacted with triphosgene in dioxane to obtain 4-isocyanatobenzonitrile $\mathbf{3}$, which was treated with different substituted anilines to get diaryl ureas $4 \mathbf{a}-\mathbf{h}$. $4 \mathbf{a}-\mathbf{h}$ were then turned into thioamides $\mathbf{5} \mathbf{a}-\mathbf{h}$ under the condition of magnesium chloride and sodium bisulfide in $N, N$-dimethylformamide. Cyclization of $\mathbf{5 a}$-h with 1,3-dichloroacetone in tetrahydrofuran readily afforded thiozoles $\mathbf{6 a}-\mathbf{h}$, which reacted with piperazine in ethanol by nucleophilic substitution to get $7 \mathbf{a}-\mathbf{h}$. Consequently, ethyl chloroacetate was added to a solution of $7 \mathbf{a}-\mathbf{h}$ in ethanol to afford esters $\mathbf{8 a}-\mathbf{h}$, followed by hydrazinolysis to obtain acylhydrazines $\mathbf{9 a}-\mathbf{h}$. Finally, target compounds $\mathbf{1 a}-\mathbf{i}$ were prepared via respective condensation of $\mathbf{9 a}-\mathbf{h}$ with various benzaldehydes and benzyloxybenzaldehydes 17 and $\mathbf{1 8}$

The synthesis of target compounds $\mathbf{2} \mathbf{a}-\mathbf{i}$ is described in

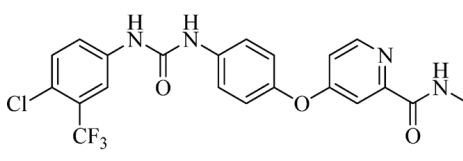

sorafenib<smiles>C=CCc1cccc(/C=N/NC(=O)CN2CCN(Cc3ccccc3)CC2)c1O</smiles>

PAC-1

Fig. 1. Structures of Sorafenib and PAC-1

The authors declare no conflict of interest. 


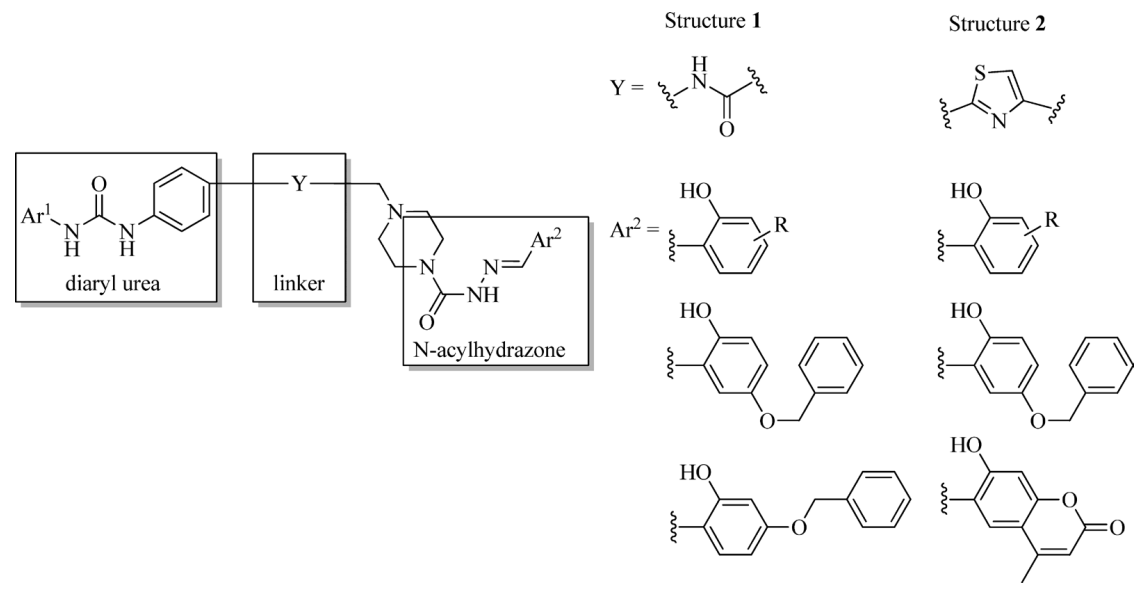

Fig. 2. The General Structures of Target Compounds

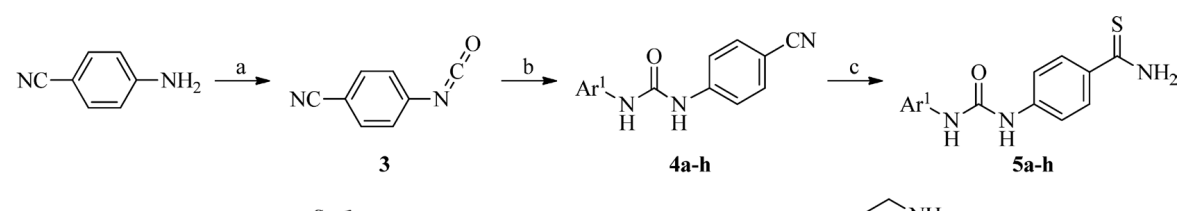

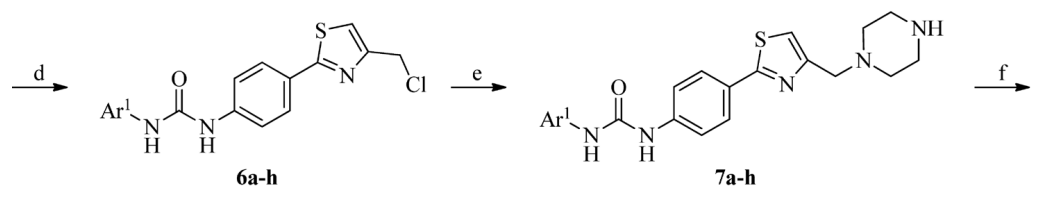<smiles>CCOC(=O)CN1CCN(Cc2csc(-c3ccc(NC(=O)N[AlH4])cc3)n2)CC1</smiles>

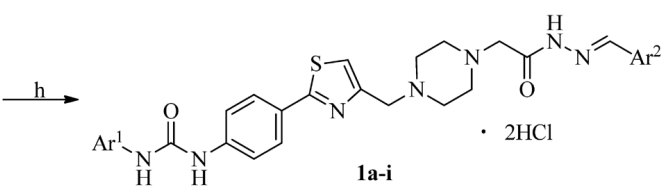

$$
\begin{aligned}
& \text { 4a-9a: } \mathrm{Ar}_{1}=2-\mathrm{CF}_{3}-\mathrm{C}_{6} \mathrm{H}_{4} \\
& \text { 4b-9b: } \mathrm{Ar}_{1}=3,5-\mathrm{Cl}^{-} \mathrm{C}_{6} \mathrm{H}_{3} \\
& \text { 4c-9c: } \mathrm{Ar}_{1}=3-\mathrm{OCF}_{3}-\mathrm{C}_{6} \mathrm{H}_{4} \\
& \text { 4d-9d: } \mathrm{Ar}_{1}=\mathrm{C}_{6} \mathrm{H}_{5} \\
& \text { 4e-9e: } \mathrm{Ar}_{1}=2-\mathrm{Cl}^{-4}-\mathrm{CF}_{3}-\mathrm{C}_{6} \mathrm{H}_{3} \\
& \text { 4f-9f: } \mathrm{Ar}_{1}=2-\mathrm{OCF}_{3}-\mathrm{C}_{6} \mathrm{H}_{4} \\
& \text { 4g-9g: } \mathrm{Ar}_{1}=3-\mathrm{Cl}_{3} \mathrm{C}_{6} \mathrm{H}_{4} \\
& \text { 4h-9h: } \mathrm{Ar}_{1}=3,4-\mathrm{Cl}_{-}-\mathrm{C}_{6} \mathrm{H}_{3}
\end{aligned}
$$

Reactions and conditions: (a) triphosgene, dioxane, $80^{\circ} \mathrm{C}, 24 \mathrm{~h}$; (b) $\mathrm{Ar}^{1} \mathrm{NH}_{2}$, THF, r.t.; (c) $\mathrm{MgCl}_{2}, \mathrm{NaSH}$, DMF, overnight; (d) 1,3 -dichloroacetone, THF, 50 ${ }^{\circ} \mathrm{C}, 7 \mathrm{~h}$; (e) piperazine, ethanol, r.t., $2 \mathrm{~h}$; (f) ethyl chloroacetate, $\mathrm{K}_{2} \mathrm{CO}_{3}, \mathrm{NaI}$, ethanol, $50^{\circ} \mathrm{C}, 2 \mathrm{~h}$; $(\mathrm{g}) 80 \%$ hydrazine hydrate, ethanol, $50^{\circ} \mathrm{C}, 48 \mathrm{~h}$; (h) i. Ar ${ }^{2} \mathrm{CHO}$ or 17 or 18 , ethanol; ii. HCl-ethanol.

Chart 1. Synthesis of Compounds $\mathbf{1 a}-\mathbf{i}$

Chart 2. 4-Nitroaniline reacted with triphosgene in dioxane to afford 1-isocyanato-4-nitrobenzene 10, which was treated with corresponding substituted anilines to give diaryl ureas 11a-d. Reduction of compounds $11 \mathbf{a}-\mathbf{d}$ in the presence of iron powder and ammonium chloride in $95 \%$ ethanol gave ureidoanilines $\mathbf{1 2} \mathbf{a}-\mathbf{d}$, followed by reaction with chloroacetyl chloride to afford chloroactetamides 13a-d, which underwent nucleophilic attack by piperazine to give $\mathbf{1 4 a}-\mathbf{d}$. According to the same procedures for the preparation of $\mathbf{1 a}-\mathbf{i}$, the desired compounds $\mathbf{2 a}-\mathbf{i}$ were obtained via respective condensation of 16a-d with various benzaldehydes, benzyloxybenzaldehyde $\mathbf{1 7}$ and chromenealdehyde $\mathbf{2 0}$.

As shown in Chart 3, benzyloxybenzaldehydes $\mathbf{1 7}$ and $\mathbf{1 8}$ were prepared from 2,5-dihydroxybenzaldehyde and 2,4-dihydroxybenzaldehyde respectively through reactions with benzyl chloride in acetonitrile in the presence of sodium bicarbonate and potassium iodide. Chromenealdehyde 20 was synthesized from benzene-1,3-diol via a two-step reaction pathway with ethyl acetoacetate and urotropine in sequence.

Biological Evaluation The cytotoxicity of target compounds $\mathbf{1} \mathbf{a}-\mathbf{i}$ and $\mathbf{2 a}-\mathbf{i}$ were evaluated against human lung adenocarcinoma epithelial cell line (A549), human breast cancer cell line (MDA-MB-231) and human leukemia cell line (HL-60) with sorafenib and PAC-1 as the positive controls. Three compounds (1a, 1f and $\mathbf{1 h}$ ) were further evaluated against human embryonic fibroblast, lung-derived cell line (WI38) in vitro. The results expressed as $\mathrm{IC}_{50}$ values were summarized in Table 1.

As listed in Table 1, most of the target compounds exhibited moderate to strong activities to the tested cell lines. Generally, compounds $\mathbf{1 a}-\mathbf{i}$ with thiazolyl linker were more potent than compounds $\mathbf{2 a}-\mathbf{i}$ with amide. It suggested that the heterocyclic ring bridging the two pharmacophores is essential for the activity, and replacement with an acyclic linker may cause a 

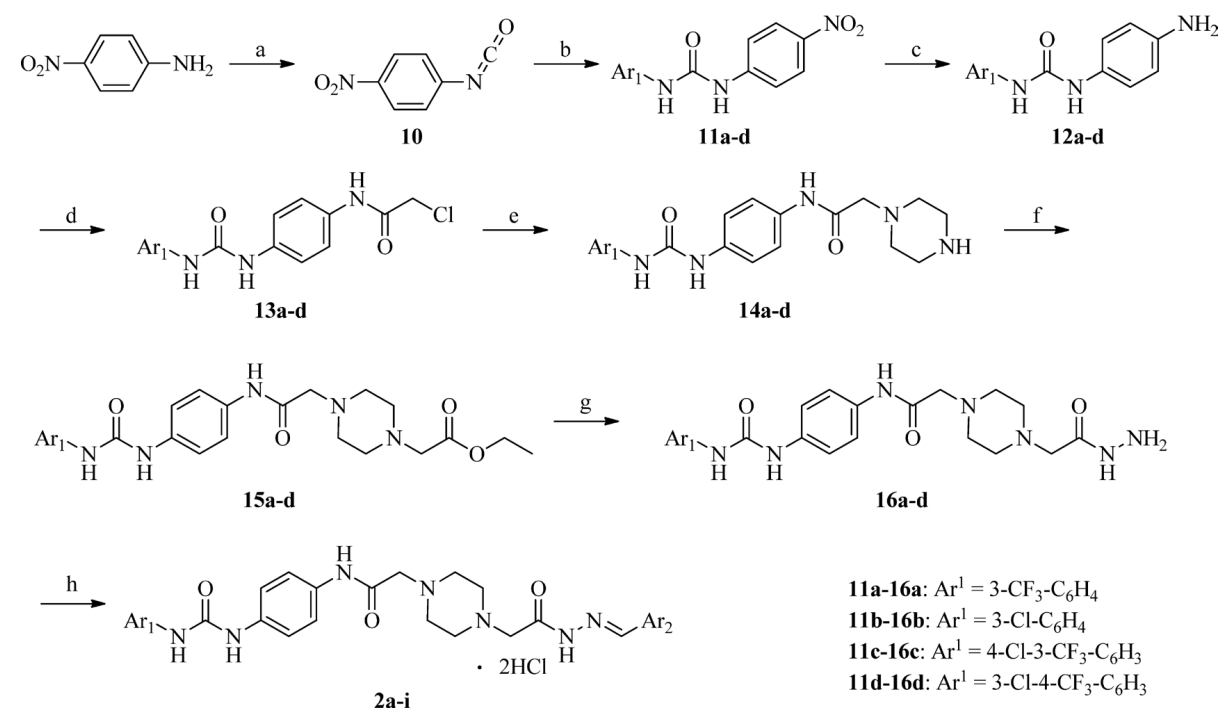

$$
\begin{aligned}
& \text { 11a-16a: } \mathrm{Ar}^{1}=3-\mathrm{CF}_{3}-\mathrm{C}_{6} \mathrm{H}_{4} \\
& \text { 11b-16b: } \mathrm{Ar}^{1}=3-\mathrm{Cl}-\mathrm{C}_{6} \mathrm{H}_{4} \\
& \text { 11c-16c: } \mathrm{Ar}^{1}=4-\mathrm{Cl}-3-\mathrm{CF}_{3}-\mathrm{C}_{6} \mathrm{H}_{3} \\
& \text { 11d-16d: } \mathrm{Ar}^{1}=3-\mathrm{Cl}-4-\mathrm{CF}_{3}-\mathrm{C}_{6} \mathrm{H}_{3}
\end{aligned}
$$

Reactions and conditions: (a) triphosgene, dioxane, $80^{\circ} \mathrm{C}, 24 \mathrm{~h}$; (b) $\mathrm{Ar}^{1} \mathrm{NH}_{2}$, THF, r.t.; (c) $\mathrm{Fe}, \mathrm{NH}_{4} \mathrm{Cl}$, $\mathrm{HOAc}$, ethanol, $80^{\circ} \mathrm{C}, 5 \mathrm{~h}$; (d) chloroacetyl chloride, $\mathrm{TEA}$, $\mathrm{CH}_{2} \mathrm{Cl}_{2}, 0^{\circ} \mathrm{C}$, r.t., $5 \mathrm{~h}$; (e) piperazine, ethanol, r.t., 6h; (f) ethyl chloroacetate, $\mathrm{K}_{2} \mathrm{CO}_{3}$, NaI, ethanol, $50^{\circ} \mathrm{C}, 2 \mathrm{~h} ;(\mathrm{g}) 80 \%$ hydrazine hydrate, ethanol, $50^{\circ} \mathrm{C}$, $48 \mathrm{~h}$; (h) i. $\mathrm{Ar}^{2} \mathrm{CHO}$ or $\mathbf{1 7}$ or $\mathbf{2 0}$, ethanol; ii. HCl-ethanol.

Chart 2. Synthesis of Compounds $\mathbf{2 a}-\mathbf{i}$<smiles>O=Cc1cc(O)ccc1OCc1ccccc1</smiles><smiles>Cc1cccc(COc2ccc(C=O)c(O)c2)c1</smiles><smiles>Cc1cc(O)c2c(C)cc(=O)oc2c1</smiles>

Reactions and conditions: (a) benzyl chloride $\mathrm{NaHCO}_{3}, \mathrm{CH}_{3} \mathrm{CN}$, r.f., $30 \mathrm{~h}$; (b) benzyl chloride, $\mathrm{NaHCO}_{3}, \mathrm{CH}_{3} \mathrm{CN}$, reflux, $30 \mathrm{~h}$; (c) ethyl acetoacetate, $\mathrm{H}_{2} \mathrm{SO}_{4}$, $10^{\circ} \mathrm{C}, 4 \mathrm{~h}$; (d) urotropine, $\mathrm{HOAc}, 115^{\circ} \mathrm{C}, 4 \mathrm{~h}$.

Chart 3. Synthesis of Intermediates 17, 18 and 20

dramatical decrease in the activity, or even a complete loss.

Compounds 1f, $\mathbf{1 g}$ and 1i with trifluoromethoxyl or trifluoromethyl group at the ortho-position and dichloro group at the meta- and para-positions of phenyl ring $\mathrm{Ar}^{1}$ repectively showed more potent cytotoxicity than compound 1d with no substituent and $\mathbf{1 h}$ with only chloro group at the meta-position. Compounds $\mathbf{2 e}$ and $\mathbf{2 g}$ with trifluoromethyl or more electron-withdrawing groups exhibited comparable cytotoxicity to sorafenib and PAC-1, while compound $\mathbf{2 f}$ with only chloro group at the meta-position of phenyl $\mathrm{Ar}^{1}$ showed no activity against A549 and MDA-MB-231 cell lines. These findings suggested that the electron-withdrawing groups on the phenyl ring $\mathrm{Ar}^{1}$ are favorable to the activity.

Compounds with alkyl groups or no substituents at the phenyl ring $\mathrm{Ar}^{2}$, e.g. compounds $1 \mathrm{c}$ and 1a, exhibited comparable activities to sorafenib and PAC-1. Compounds $\mathbf{1 f}$ and $1 \mathrm{~g}$ with the benzyloxyl group at the 5-position of the phenyl ring showed a remarkable increase in the activity, especially compound 1 fisplayed the most potent activity with $\mathrm{IC}_{50}$ values of $0.41 \mu \mathrm{M}, 0.24 \mu \mathrm{M}$ and $0.23 \mu \mathrm{M}$, respectively, which were 3.2- to 19.8-fold higher than sorafenib and PAC-1. However, compounds $\mathbf{1 h}$ and $\mathbf{1 i}$ with the benzyloxyl group at the 4-position of the phenyl ring did not show a similar result. These findings indicated that the aryl substituent at the 5-position of $\mathrm{Ar}^{2}$ would significantly enhance the cytotoxicity.

To investigate the effect of a heterocylic ring for $\mathrm{Ar}^{2}$, we replaced the phenyl group with a substituted chromenonyl group to obtained compounds $\mathbf{2 h}$ and $\mathbf{2 i}$. Unfortunately, these compounds exhibited even lower inhibition activities than the unfavored compounds $\mathbf{2 a - g}$. It suggested that the phenyl group substituted at $\mathrm{Ar}^{2}$ is critical for the activity.

Compounds 1a, 1f and $\mathbf{1 h}$ exerted weaker cytotoxicity against WI38 (the normal cell line) than the three cancer cell lines. The most promising compound 1f possessed selective indexes $\left(\mathrm{IC}_{50}\right.$ normal cell/ $\mathrm{IC}_{50}$ cancer cell) of 11,19 and 20 for A549, MDA-MB-231 and HL-60 cell lines, respectively.

\section{Conclusion}

In summary, a new series of diaryl urea derivatives bearing $N$-acylhydrazone moiety were designed and synthesized. All the compounds were screened for their cytotoxicity against A549, MDA-MB-231 and HL-60 cell lines. The pharmacological results indicated that some of the prepared compounds showed promising activities. Compound 1f showed the most potent cytotoxicity against A549, MDA-MB-231 and HL-60 cell lines with $\mathrm{IC}_{50}$ values of $0.41 \mu \mathrm{M}, 0.24 \mu \mathrm{M}$ and $0.23 \mu \mathrm{M}$, repectively, which were 3.2- to 19.8-fold higher than sorafenib and PAC-1. Moreover, compound 1f exhibited the most selective cytotoxicity against the three cancer cell lines when compared with WI38 cell line. The preliminary strucuture-activity relationships (SARs) showed that the thiazolyl linker and the phenyl group of $\mathrm{Ar}^{2}$ are favorable for the activity. Moreover, electron-withdrawing groups on $\mathrm{Ar}^{1}$ and the benzyloxy group at the 5-position of phenyl ring $\mathrm{Ar}^{2}$ could enhance the activity. These investigations prompt us to carry on further studies on their mechanisms of action.

\section{Experimental}

Chemistry Melting points were obtained on a Büchi 
Table 1. Structures and Cytotoxicity of Compounds 1a-i and 2a-i against A549, MDA-MB-231, HL-60 and WI38 Cell Lines

\begin{tabular}{|c|c|c|c|c|c|c|}
\hline \multirow{2}{*}{ Compd. } & \multirow{2}{*}{$\mathrm{Ar}^{1}$} & \multirow{2}{*}{$\mathrm{Ar}^{2}$} & \multicolumn{4}{|c|}{$\mathrm{IC}_{50}(\mu \mathrm{M})$} \\
\hline & & & A549 & MDA-MB-231 & HL-60 & WI38 \\
\hline 1a & & & 3.88 & 4.65 & 2.40 & 11.67 \\
\hline $1 \mathrm{~b}$ & & & 2.40 & 1.27 & 0.33 & $\mathrm{ND}^{a}$ \\
\hline 1c & & & 1.49 & 0.90 & 2.11 & $\mathrm{ND}^{a)}$ \\
\hline 1d & & & 1.67 & 0.74 & 0.55 & $\mathrm{ND}^{a)}$ \\
\hline $1 e$ & & & 2.30 & 0.59 & 1.03 & $\mathrm{ND}^{a}$ \\
\hline 1f & & & 0.41 & 0.24 & 0.23 & 4.53 \\
\hline $1 \mathrm{~g}$ & & & 0.45 & 0.30 & 0.35 & $\mathrm{ND}^{a)}$ \\
\hline $1 \mathrm{~h}$ & & & 0.83 & 0.52 & 1.18 & 6.91 \\
\hline $1 \mathbf{i}$ & & & 0.78 & 0.47 & 0.80 & $\mathrm{ND}^{a)}$ \\
\hline $2 a$ & & & 8.97 & 2.39 & 4.24 & $\mathrm{ND}^{a}$ \\
\hline $2 b$ & & & 1.34 & 0.49 & 1.29 & $\mathrm{ND}^{a}$ \\
\hline $2 c$ & & & 52.0 & 1.18 & 2.44 & $\mathrm{ND}^{a}$ \\
\hline 2d & & & 10.7 & 1.07 & 4.42 & $\mathrm{ND}^{a}$ \\
\hline $2 e$ & & & 3.16 & 1.48 & 2.66 & $\mathrm{ND}^{a}$ \\
\hline $2 f$ & & & $>100$ & $>100$ & 1.70 & $\mathrm{ND}^{a}$ \\
\hline
\end{tabular}


Table 1. Structures and Cytotoxicity of Compounds 1a-i and 2a-i against A549, MDA-MB-231, HL-60 and WI38 Cell Lines

\begin{tabular}{|c|c|c|c|c|c|c|}
\hline \multirow{2}{*}{ Compd. } & \multirow{2}{*}{$\mathrm{Ar}^{1}$} & \multirow{2}{*}{$\mathrm{Ar}^{2}$} & \multicolumn{4}{|c|}{$\mathrm{IC}_{50}(\mu \mathrm{M})$} \\
\hline & & & A549 & MDA-MB-231 & HL-60 & WI38 \\
\hline $2 \mathrm{~g}$ & & & 4.02 & 1.92 & 1.82 & $\left.\mathrm{ND}^{a}\right)$ \\
\hline $2 \mathrm{~h}$ & & & 18.0 & $>100$ & 5.54 & $\mathrm{ND}^{a)}$ \\
\hline $2 \mathrm{i}$ & & & $>100$ & 8.92 & 3.08 & $\mathrm{ND}^{a)}$ \\
\hline Sorafenib & & & 1.30 & 2.70 & $\mathrm{ND}^{a)}$ & 10.8 \\
\hline PAC-1 & & & 2.81 & 2.04 & 4.56 & 6.63 \\
\hline
\end{tabular}

a) ND: not determined.

Melting Point B-540 apparatus (Büchi Labortechnik, Flawil, Switzerland) and were uncorrected. Mass spectra (MS) were taken in electrospray ionization (ESI) mode on Agilent 1100 LC-MS (Agilent, Palo Alto, CA, U.S.A.). Proton $\left({ }^{1} \mathrm{H}\right)$ nuclear magnetic resonance spectroscopy was performed using Bruker ARX-300, $300 \mathrm{MHz}$ spectrometers (Bruker Bioscience, Billerica, MA, U.S.A.) with tetramethylsilane (TMS) as an internal standard. Unless otherwise noted, all the materials were obtained from commercial available sources and were used without further purification.

4-Isocyanatobenzonitrile (3) 4-Aminobezonitrile (100 g, $0.847 \mathrm{~mol}$ ) was treated with excess hydrochloride-ethanol and the resulted solution was evaporated to dryness. The hydrochloride salt obtained was then dissolved in dioxane $(200 \mathrm{~mL})$ and added dropwise to a solution of triphosgene $(125 \mathrm{~g}, 0.423 \mathrm{~mol})$ in dioxane $(200 \mathrm{~mL})$. The reaction mixture was heated to $50^{\circ} \mathrm{C}$ and stirred for $24 \mathrm{~h}$. The resulting mixture was concentrated in vacuo and distilled under reduced pressure to give $3(103 \mathrm{~g}, 84.4 \%)$ as colorless oil. bp: $130-131^{\circ} \mathrm{C}$ (15 mmHg).

General Procedure for the Preparation of 1-(4-Cyanophenyl)-3-substituted Phenylureas $(\mathbf{4 a - h )}$ To a solution of $3(16 \mathrm{~g}, 0.111 \mathrm{~mol})$ in tetrahydrofuran $(100 \mathrm{~mL})$ was added the corresponding substituted aniline $(0.111 \mathrm{~mol})$ slowly. The resulted mixture was stirred at room temperature and the reaction was monitored by TLC. The reaction mixture was concentrated in vacuo. the product that precipitated was filtered and dried to obtain $\mathbf{4 a}-\mathbf{h}$.

1-(4-Cyanophenyl)-3-(2-trifluoromethylphenyl)urea

Yield 85.8\%. ESI-MS m/z: $306.1(\mathrm{M}+\mathrm{H})^{+}$.

1-(4-Cyanophenyl)-3-(3,5-dichlorophenyl)urea (4b): Yield 83.4\%. ESI-MS m/z: $306.1(\mathrm{M}+\mathrm{H})^{+}$.

1-(4-Cyanophenyl)-3-(3-trifluoromethoxyphenyl)urea Yield 79.7\%. ESI-MS m/z: $322.2(\mathrm{M}+\mathrm{H})^{+}$.

1-(4-Cyanophenyl)-3-phenylurea (4d): Yield 87.1\%. ESI-MS $m / z: 238.1(\mathrm{M}+\mathrm{H})^{+}$.

1-(2-Chloro-4-trifluoromethylphenyl)-3-(4-cyanophenyl)urea (4e): Yield 85.3\%. ESI-MS m/z: $340.0(\mathrm{M}+\mathrm{H})^{+}$.

1-(4-Cyanophenyl)-3-(2-trifluoromethoxyphenyl)urea

Yield 80.4\%. ESI-MS m/z: $322.1(\mathrm{M}+\mathrm{H})^{+}$.

1-(3-Chlorophenyl)-3-(4-cyanophenyl)urea (4g): Yield
77.5\%. ESI-MS m/z: $272.0(\mathrm{M}+\mathrm{H})^{+}$.

1-(4-Cyanophenyl)-3-(3,4-dichlorophenyl)urea (4h): Yield 82.5\%. ESI-MS m/z: $306.0(\mathrm{M}+\mathrm{H})^{+}$.

General Procedure for the Preparation of 4-(3-Substituted phenylureido)benzothioamides $(5 \mathbf{a}-\mathbf{h})$ To a solution of benzonitrile $(\mathbf{4 a}-\mathbf{h})(0.086 \mathrm{~mol})$ in $N, N$-dimethylformamide $(250 \mathrm{~mL})$ was added magnesium chloride $(22 \mathrm{~g}, 0.109 \mathrm{~mol})$ and sodium bisulfide $(12.2 \mathrm{~g}, 0.218 \mathrm{~mol})$. The reaction mixture was stirred at room temperature overnight and then was added to $1 \mathrm{~L}$ water, acidified to $\mathrm{pH} 4$ with dilute hydrochloride and filtered. The collected solid was washed with water until the filtrate became neutral and dried to obtain 5a-h (47.6-59.2\%).

General Procedure for the Preparation of 1-(4-(4Chloromethylthiazol-2-yl)phenyl)-3-substituted Phenylureas (6a-h) Benzothioamide (5a-h) $(0.083 \mathrm{~mol})$ was dissolved in THF $(300 \mathrm{~mL})$ and heated to $50^{\circ} \mathrm{C}$. To the stirred solution was added 1,3-dichloroacetone $(10.5 \mathrm{~g}, 0.083 \mathrm{~mol})$. The reaction mixture was stirred for $7 \mathrm{~h}$. The resulting mixture was evaporated in vacuo to remove most of the solvent, cooled and filtered off. The residue was suspended in $1 \mathrm{~L}$ water and the suspension was stirred and basified to $\mathrm{pH} 8$ with saturated potassium carbonate solution. The precipitates was filtered, washed with water and dried to obtain $\mathbf{6 a}-\mathbf{h}(74.2-80.0 \%)$.

General Procedure for the Preparation of 1-Substituted Phenyl-3-(4-(4-(piperazin-1-ylmethyl)thiazol-2-yl)phenyl)ureas $(7 \mathbf{a}-\mathbf{h})$ To a solution of piperazine $(64 \mathrm{~g}, 0.748 \mathrm{~mol})$ in ethanol was added urea $(6 \mathbf{6}-\mathbf{h})$ in portions. The reaction mixture was stirred at room temperature for $2 \mathrm{~h}$. The resulting mixture was evaporated in vacuo to remove most of the solvent and poured into $1.5 \mathrm{~L}$ water. The white precipitates was filtered, washed with water and dried to obtain $7 \mathbf{a}-\mathbf{h}$.

1-(4-(4-(Piperazin-1-ylmethyl)thiazol-2-yl)phenyl)-3-(2trifluoromethylphenyl)urea (7a): Yield $58.2 \%$. ESI-MS $\mathrm{m} / \mathrm{z}$ : $462.2(\mathrm{M}+\mathrm{H})^{+}$.

1-(3,5-Dichlorophenyl)-3-(4-(4-(piperazin-1-ylmethyl)thiazol-2-yl)phenyl)urea (7b): Yield 55.4\%. ESI-MS m/z: 462.2 $(\mathrm{M}+\mathrm{H})^{+}$.

1-(4-(4-(Piperazin-1-ylmethyl)thiazol-2-yl)phenyl)-3-(3trifluoromethoxyphenyl)urea (7c): Yield 63.7\%. ESI-MS $\mathrm{m} / \mathrm{z}$ : $478.3(\mathrm{M}+\mathrm{H})^{+}$.

1-Phenyl-3-(4-(4-(piperazin-1-ylmethyl)thiazol-2-yl)phenyl)- 
urea (7d): Yield 55.9\%. ESI-MS $m / z: 394.2(\mathrm{M}+\mathrm{H})^{+}$.

1-(2-Chloro-4-trifluoromethylphenyl)-3-(4-(4-(piperazin-1ylmethyl)thiazol-2-yl)phenyl)urea (7e): Yield 51.8\%. ESI-MS $m / z: 496.1(\mathrm{M}+\mathrm{H})^{+}$.

1-(4-(4-(Piperazin-1-ylmethyl)thiazol-2-yl)phenyl)-3-(2trifluoromethoxyphenyl)urea (7f): Yield 58.4\%. ESI-MS $\mathrm{m} / \mathrm{z}$ : $478.1(\mathrm{M}+\mathrm{H})^{+}$.

1-(3-Chlorophenyl)-3-(4-(4-(piperazin-1-ylmethyl)thiazol-2yl)phenyl)urea (7g): Yield 50.7\%. ESI-MS m/z: $428.1(\mathrm{M}+\mathrm{H})^{+}$.

1-(3,4-Dichlorophenyl)-3-(4-(4-(piperazin-1-ylmethyl)thiazol-2-yl)phenyl)urea (7h): Yield 53.0\%. ESI-MS m/z: 462.0 $(\mathrm{M}+\mathrm{H})^{+}$.

General Procedure for the Preparation of Ethyl 2(4-((2-(4-(3-Substituted phenylureido)phenyl)thiazol-4-yl)methyl)piperazin-1-yl)acetates $(\mathbf{8 a}-\mathbf{h})$ To a solution of $\mathrm{N}$ substituted piperazine $(\mathbf{7 a}-\mathbf{h})(0.063 \mathrm{~mol})$ in ethanol $(300 \mathrm{~mL})$ was added potassium carbonate $(5.2 \mathrm{~g}, 0.038 \mathrm{~mol})$, ethyl chloroacetate $(7.7 \mathrm{~g}, 0.063 \mathrm{~mol})$ and sodium iodide (cat.). The reaction mixture was heated to $50^{\circ} \mathrm{C}$ and stirred for $2 \mathrm{~h}$. The reaction mixture was concentrated in vacuo and cooled. The product precipitated was filtered off, washed with ethanol and water, and dried to obtain $\mathbf{8 a}-\mathbf{h}(87.5-92.1 \%)$.

General Procedure for the Preparation of 1-Substituted Phenyl-3-(4-(4-((4-(2-hydrazinyl-2-oxoethyl)piperazin-1yl)methyl)thiazol-2-yl)phenyl)ureas $(\mathbf{9 a}-\mathbf{h}) \quad$ To a solution of ester $(\mathbf{8 a}-\mathbf{h})(0.044 \mathrm{~mol})$ in ethanol $(250 \mathrm{~mL})$ was added $80 \%$ hydrazine hydrate $(27.7 \mathrm{~g}, 0.443 \mathrm{~mol})$. The reaction mixture was heated to $50^{\circ} \mathrm{C}$ and stirred for $48 \mathrm{~h}$. The reaction mixture was evaporated to remove most of the solvent. The residue was filtered off, washed with water, and dried to obtain $\mathbf{9 a - h}$.

1-(4-(4-((4-(2-Hydrazinyl-2-oxoethyl)piperazin-1-yl)methyl)thiazol-2-yl)phenyl)-3-(2-trifluoromethylphenyl)urea

Yield 89.8\%. ESI-MS m/z: $534.2(\mathrm{M}+\mathrm{H})^{+}$.

1-(3,5-Dichlorophenyl)-3-(4-(4-((4-(2-hydrazinyl-2oxoethyl)piperazin-1-yl)methyl)thiazol-2-yl)phenyl)urea Yield $88.0 \%$. ESI-MS $m / z$ : $534.2(\mathrm{M}+\mathrm{H})^{+}$.

1-(4-(4-((4-(2-Hydrazinyl-2-oxoethyl)piperazin-1-yl)methyl)thiazol-2-yl)phenyl)-3-(3-trifluoromethoxyphenyl)urea

Yield 92.6\%. ESI-MS m/z: $550.2(\mathrm{M}+\mathrm{H})^{+}$.

1-(4-(4-((4-(2-Hydrazinyl-2-oxoethyl)piperazin-1-yl)methyl)thiazol-2-yl)phenyl)-3-phenylurea (9d): Yield 88.7\%. ESI-MS $m / z: 466.2(\mathrm{M}+\mathrm{H})^{+}$.

1-(2-Chloro-4-trifluoromethylphenyl)-3-(4-(4-((4-(2hydrazinyl-2-oxoethyl)piperazin-1-yl)methyl)thiazol-2-yl)phenyl)urea (9e): Yield 85.2\%. ESI-MS $m / z$ : $568.1(\mathrm{M}+\mathrm{H})^{+}$.

1-(4-(4-((4-(2-Hydrazinyl-2-oxoethyl)piperazin-1-yl)methyl)thiazol-2-yl)phenyl)-3-(2-(trifluoromethoxy)phenyl)urea (9f): Yield 90.4\%. ESI-MS $m / z$ : $550.3(\mathrm{M}+\mathrm{H})^{+}$.

1-(3-Chlorophenyl)-3-(4-(4-((4-(2-hydrazinyl-2-oxoethyl)piperazin-1-yl)methyl)thiazol-2-yl)phenyl)urea $\quad(9 \mathrm{~g})$ : Yield $87.5 \%$. ESI-MS $m / z: 500.2(\mathrm{M}+\mathrm{H})^{+}$.

1-(3,4-Dichlorophenyl)-3-(4-(4-((4-(2-hydrazinyl-2oxoethyl)piperazin-1-yl)methyl)thiazol-2-yl)phenyl)urea Yield 86.7\%. ESI-MS $m / z$ : $534.1(\mathrm{M}+\mathrm{H})^{+}$.

1-Isocyanato-4-nitrobenzene (10) 4-Nitroaniline (100 g, $0.725 \mathrm{~mol}$ ) was treated with excess hydrochloride-ethanol and evaporated to dryness. The hydrochloride salt obtained was then dissolved in dioxane $(200 \mathrm{~mL})$ and added dropwise to a solution of triphosgene $(108 \mathrm{~g}, 0.362 \mathrm{~mol})$ in dioxane $(200 \mathrm{~mL})$. The reaction mixture was heated to $50^{\circ} \mathrm{C}$ and stirred for $24 \mathrm{~h}$. The resulting mixture was concentrated in vacuo and distilled under reduced pressure to give $\mathbf{1 0}(70 \mathrm{~g}, 58.9 \%)$ as yellow solid. bp: $168-170^{\circ} \mathrm{C}(15 \mathrm{mmHg})$.

General Procedure for the Preparation of 1-(4-Nitrophenyl)-3-substituted phenylureas (11a-d) To a solution of $\mathbf{1 0}(40 \mathrm{~g}, 0.244 \mathrm{~mol})$ in tetrahydrofuran $(500 \mathrm{~mL})$ was added the corresponding substituted aniline $(0.244 \mathrm{~mol})$ slowly. The resulted mixture was stirred at room temperature and the reaction was monitored by TLC. The reaction mixture was concentrated in vacuo and filtered. The solid was dried to obtain 11a-d.

1-(4-Nitrophenyl)-3-(3-(trifluoromethyl)phenyl)urea Yield $75.7 \%$. ESI-MS $m / z$ : $326.2(\mathrm{M}+\mathrm{H})^{+}$.

1-(3-Chlorophenyl)-3-(4-nitrophenyl)urea (11b): Yield 80.1\%. ESI-MS m/z: $292.1(\mathrm{M}+\mathrm{H})^{+}$.

1-(4-Chloro-3-(trifluoromethyl)phenyl)-3-(4-nitrophenyl)urea (11c): Yield 81.4\%. ESI-MS m/z: $360.0(\mathrm{M}+\mathrm{H})^{+}$.

1-(3-Chloro-4-(trifluoromethyl)phenyl)-3-(4-nitrophenyl)urea (11d): Yield 72.4\%. ESI-MS $m / z: 360.0(\mathrm{M}+\mathrm{H})^{+}$.

General Procedure for the Preparation of 1-(4-Aminophenyl)-3-substituted phenylureas (12a-d) To a stirred solution of ureidonitrobenzene (11a-d) $(0.185 \mathrm{~mol})$ in $95 \%$ ethanol $(500 \mathrm{~mL})$ was added glacial acetic acid $(5 \mathrm{~mL})$, ammonium chloride $(15 \mathrm{~g}, 0.280 \mathrm{~mol})$ and iron powder $(62 \mathrm{~g}$, $1.107 \mathrm{~mol})$. The mixture was heated to $80^{\circ} \mathrm{C}$ and stirred for $5 \mathrm{~h}$. The reaction mixture was filtered hot. The filtrate was concentrated in vacuo and poured into water $(500 \mathrm{~mL})$. The precipitates were filtered off and dried to afford $12 \mathbf{a}-\mathbf{d}$ (93.1-98.2\%).

General Procedure for the Preparation of 2-Chloro$N$-(4-(3-substituted phenylureido)phenyl)acetamides (13ad) A solution of amine $(\mathbf{1 2 a}-\mathbf{d})(0.183 \mathrm{~mol})$ and triethylamine $(28 \mathrm{~g}, 0.277 \mathrm{~mol})$ in dichloromethane $(500 \mathrm{~mL})$ was cooled below $0{ }^{\circ} \mathrm{C}$ in an ice-salt bath and chloroacetyl chloride $(25 \mathrm{~g}$, $0.221 \mathrm{~mol}$ ) was added dropwise. The ice-salt bath was removed and the resulting mixture was stirred at room temperature for $5 \mathrm{~h}$. The precipitates were filtered off, washed with dichloromethane and dried to afford 13a-d (88.6-91.2\%).

General Procedure for the Preparation of 2-(Piperazin1-yl)-N-(4-(3-substituted phenylureido)phenyl)acetamides (14a-d) To a stirred solution of piperazine (194 g, $1 \mathrm{~mol})$ in ethanol $(500 \mathrm{~mL})$ was added chloroactetamide $(\mathbf{1 3 a}-\mathbf{d})$ $(0.500 \mathrm{~mol})$ in portions. The reaction mixture was stirred at room temperature for $6 \mathrm{~h}$. The resulting mixture was evaporated in vacuo to remove the solvent and then poured into water $(500 \mathrm{~mL})$. The precipitates were filtered off, washed with water and dried to give $\mathbf{1 4 a}-\mathbf{d}$.

2-(Piperazin-1-yl)- $N$-(4-(3-(3-trifluoromethyl)phenylureido)phenyl)acetamide (14a): Yield 68.9\%. ESI-MS $\mathrm{m} / \mathrm{z}: 422.2$ $(\mathrm{M}+\mathrm{H})^{+}$.

$N$-(4-(3-(3-Chlorophenyl)ureido)phenyl)-2-(piperazin-1-yl)acetamide (14b): Yield 72.1\%. ESI-MS $m / z$ : $388.1(\mathrm{M}+\mathrm{H})^{+}$.

$\mathrm{N}$-(4-(3-(4-Chloro-3-(trifluoromethyl)phenyl)ureido)phenyl)-2-(piperazin-1-yl)acetamide (14c): Yield 65.4\%. ESIMS $m / z: 456.1(\mathrm{M}+\mathrm{H})^{+}$.

$\mathrm{N}$-(4-(3-(3-Chloro-4-(trifluoromethyl)phenyl)ureido)phenyl)-2-(piperazin-1-yl)acetamide (14d): Yield 69.6\%. ESIMS $m / z$ : $456.1(\mathrm{M}+\mathrm{H})^{+}$.

General Procedure for the Preparation of Ethyl 2-(4(2-Oxo-2-((4-(3-substituted phenylureido)phenyl)amino)ethyl)piperazin-1-yl)acetates (15a-d) To a solution of $N$ substituted piperazine $(\mathbf{1 4 a}-\mathbf{d})(0.157 \mathrm{~mol})$ in ethanol $(500 \mathrm{~mL})$ 
was added sodium dicarbonate $(20 \mathrm{~g}, 0.238 \mathrm{~mol})$ and ethyl chloroacetate $(21 \mathrm{~g}, 0.171 \mathrm{~mol})$. The reaction mixture was heated to $65^{\circ} \mathrm{C}$ and stirred for $20 \mathrm{~h}$. The mixture was concentrated to about $200 \mathrm{~mL}$ in vacuo and cooled to room temperature. The precipitates were filtered off and dried to afford $\mathbf{1 5} \mathbf{a}-\mathbf{d}$ (82.3-86.4\%).

General Procedure for the Preparation of 2-(4-(2Hydrazinyl-2-oxoethyl)piperazin-1-yl)- $\mathrm{N}$-(4-(3-substituted phenylureido)phenyl)acetamides $(\mathbf{1 6} \mathbf{a}-\mathbf{d})$ To a solution of ester $(\mathbf{1 5 a}-\mathbf{d})(0.059 \mathrm{~mol})$ in ethanol $(300 \mathrm{~mL})$ was added $80 \%$ hydrazine hydrate $(37 \mathrm{~g}, 0.592 \mathrm{~mol})$. The reaction mixture was heated to $50^{\circ} \mathrm{C}$ and stirred for $48 \mathrm{~h}$. The precipitates were filtered off and dried to afford $\mathbf{1 6 a}-\mathbf{d}$.

2-(4-(2-Hydrazinyl-2-oxoethyl)piperazin-1-yl)- $N$-(4-(3-(3(trifluoromethyl)phenyl)ureido)phenyl)acetamide (16a): Yield 81.2\%. ESI-MS m/z: $494.2(\mathrm{M}+\mathrm{H})^{+}$.

$N$-(4-(3-(3-Chlorophenyl)ureido)phenyl)-2-(4-(2hydrazinyl-2-oxoethyl)piperazin-1-yl)acetamide (16b): Yield 85.4\%. ESI-MS $m / z: 460.2(\mathrm{M}+\mathrm{H})^{+}$.

$N$-(4-(3-(4-Chloro-3-(trifluoromethyl)phenyl)ureido)phenyl)-2-(4-(2-hydrazinyl-2-oxoethyl)piperazin-1-yl)acetamide (16c): Yield 77.5\%. ESI-MS m/z: $528.2(\mathrm{M}+\mathrm{H})^{+}$.

$\mathrm{N}$-(4-(3-(3-Chloro-4-(trifluoromethyl)phenyl)ureido)phenyl)-2-(4-(2-hydrazinyl-2-oxoethyl)piperazin-1-yl)acetamide (16d): Yield 81.1\%. ESI-MS m/z: $528.2(\mathrm{M}+\mathrm{H})^{+}$.

5-Benzyloxy-2-hydroxybenzaldehyde (17) To a solution of 2,5-dihydroxybenzaldehyde $(50 \mathrm{~g}, 0.362 \mathrm{~mol})$ in acetonitrile $(500 \mathrm{~mL})$ was added benzyl chloride $(60 \mathrm{~g}, 0.471 \mathrm{~mol})$, sodium bicarbonate $(35 \mathrm{~g}, 0.413 \mathrm{~mol})$ and potassium iodide (cat.). The reaction mixture was heated to reflux and stirred for $30 \mathrm{~h}$. The mixture was poured into water $(500 \mathrm{~mL})$. The precipitates were filtered off, dried, recrystallized from methanol to give $17(46.5 \mathrm{~g}, 56.3 \%)$ as white solid. ESI-MS m/z: $227.1(\mathrm{M}-\mathrm{H})^{-}$.

4-Benzyloxy-2-hydroxybenzaldehyde (18) To a solution of 2,4-dihydroxybenzaldehyde $(50 \mathrm{~g}, 0.362 \mathrm{~mol})$ in acetonitrile $(500 \mathrm{~mL})$ was added benzyl chloride $(60 \mathrm{~g}, 0.471 \mathrm{~mol})$, sodium bicarbonate $(35 \mathrm{~g}, 0.413 \mathrm{~mol})$ and potassium iodide (cat.). The reaction mixture was heated to reflux and stirred for $30 \mathrm{~h}$. The mixture was poured into water $(500 \mathrm{~mL})$. The precipitates were filtered off, dried, recrystallized from methanol to give $18(43.6 \mathrm{~g}, 52.8 \%)$ as white solid. ESI-MS $m / z: 227.1(\mathrm{M}-\mathrm{H})^{-}$.

7-Hydroxy-4-methyl-2H-chromen-2-one (19) Sulfuric acid $(500 \mathrm{~mL})$ was cooled below $10^{\circ} \mathrm{C}$ in an ice-salt bath, and to the cooled acid was slowly added a solution of benzene-1,3diol $(55 \mathrm{~g}, 0.500 \mathrm{~mol})$ in ethyl acetoacetate $(65 \mathrm{~g}, 0.500 \mathrm{~mol})$. The reaction mixture was stirred for $4 \mathrm{~h}$. The resulting mixture was poured onto cracked ice and stirred. The precipitates were filtered off, washed with water and dried to afford 19 $(67.0 \mathrm{~g}, 76.1 \%)$ as white solid. ESI-MS $m / z$ : $175.1(\mathrm{M}-\mathrm{H})^{-}$.

7-Hydroxy-4-methyl-2-oxo-2H-chromene-6-carbaldehyde (20) A suspension of urotropine $(20 \mathrm{~g}, 0.143 \mathrm{~mol})$ in glacial acetic acid $(80 \mathrm{~mL})$ was heated to $40^{\circ} \mathrm{C}$ and stirred to form a clear solution. To this solution was added $19(5 \mathrm{~g}$, $0.028 \mathrm{~mol}$ ) in portions. The reaction mixture was stirred for $20 \mathrm{~min}$ and then heated to $115^{\circ} \mathrm{C}$ and stirred for another $2 \mathrm{~h}$. Finally the reaction mixture was cooled to $95^{\circ} \mathrm{C}, 30 \%$ sulfuric acid $(15 \mathrm{~mL})$ was added and the reaction continued for $1.5 \mathrm{~h}$. The resulting mixture was evaporated to dryness and the dry residue obtained was extracted with ether. The organic layer was then washed with saturated sodium bicarbonate solution, dried over anhydrous sodium sulfate and evaporated to dryness to afford $20(2.2 \mathrm{~g}, 38.0 \%)$ as white solid. ESI-MS $m / z: 203.0(\mathrm{M}-\mathrm{H})^{-}$.

General Procedure for the Preparation of Target Compounds $1 \mathbf{a}-\mathbf{i}$ and $2 \mathbf{a}-\mathbf{i}$ To a solution of acethydrazide $(9 \mathbf{a}-\mathbf{h}$, 16a-d) $(0.002 \mathrm{~mol})$ in ethanol $(10 \mathrm{~mL})$ was added appropriate benzaldehyde or the prepared aromatic aldehyde $(\mathbf{1 7}, \mathbf{1 8}, \mathbf{2 0})$. The reaction mixture was stirred and refluxed for $2 \mathrm{~h}$. The reaction mixture was cooled and precipitates were collected by filtration to obtain the crude product, which was then purified by flash column chromatography. The pure product was dissolved in chloroform. To the solution was added excessive hydrochloride-ethanol and stirred for $1 \mathrm{~h}$. Ether was added to the mixture above. The precipitates were filtered off and dried to afford $\mathbf{1 a}-\mathbf{i}$ and $\mathbf{2} \mathbf{a}-\mathbf{i}$.

1-(4-(4-((4-(2-(2-(2-Hydroxybenzylidene)hydrazinyl)-2oxoethyl)piperazin-1-yl)methyl)thiazol-2-yl)phenyl)-3-(2trifluoromethylphenyl)urea Dihydrochloride (1a): Yield 55.8\%. mp $186-188^{\circ} \mathrm{C}$. ESI-MS $m / z: 638.2(\mathrm{M}+\mathrm{H})^{+} .{ }^{1} \mathrm{H}-\mathrm{NMR}$ $\left(300 \mathrm{MHz}, \mathrm{DMSO}-d_{6}\right) \delta: 11.96(\mathrm{~s}, 1 \mathrm{H}), 10.15(\mathrm{~s}, 1 \mathrm{H}), 8.42-8.37$ $(\mathrm{m}, 2 \mathrm{H}), 7.95-7.88(\mathrm{~m}, 5 \mathrm{H}), 7.77-7.64(\mathrm{~m}, 5 \mathrm{H}), 7.34-7.24(\mathrm{~m}$, 2H), 7.01-6.84 (m, 2H), 4.58 (s, 1H), 4.48 (s, 2H), 3.81 (s, 1H), 3.66 (brs, $8 \mathrm{H})$.

1-(3,5-Dichlorophenyl)-3-(4-(4-((4-(2-(2-(2-hydroxybenzylidene)hydrazinyl)-2-oxoethyl)piperazin-1-yl)methyl)thiazol-2yl)phenyl)urea Dihydrochloride (1b): Yield 53.3\%. mp $230-232^{\circ} \mathrm{C}$. ESI-MS m/z: $638.3(\mathrm{M}+\mathrm{H})^{+} .{ }^{1} \mathrm{H}-\mathrm{NMR}(300 \mathrm{MHz}$, DMSO- $\left.d_{6}\right) \delta$ : $11.98(\mathrm{~s}, 1 \mathrm{H}), 10.15-10.01(\mathrm{~m}, 3 \mathrm{H}), 8.38(\mathrm{~s}$, $1 \mathrm{H}), 7.94(\mathrm{~d}, J=8.6 \mathrm{~Hz}, 3 \mathrm{H}), 7.76(\mathrm{~d}, J=7.8 \mathrm{~Hz}, 1 \mathrm{H}), 7.63(\mathrm{~d}$, $J=8.6 \mathrm{~Hz}, 2 \mathrm{H}), 7.54$ (s, 2H), 7.29-7.23 (m, 1H), $7.16(\mathrm{~s}, 1 \mathrm{H})$, 6.95-6.84 (m, 2H), 4.63 (s, 1H), 4.53 (s, 2H), 3.99 (s, 1H), 3.64 (brs, $8 \mathrm{H})$.

1-(4-(4-((4-(2-(2-(3,5-Di-tert-butyl-2-hydroxybenzylidene)hydrazinyl)-2-oxoethyl)piperazin-1-yl)methyl)thiazol-2-yl)phenyl)-3-(3-trifluoromethoxyphenyl)urea Dihydrochloride (1c): Yield 59.7\%. mp 221-222 ${ }^{\circ} \mathrm{C}$. ESI-MS $m / z$ : $766.2(\mathrm{M}+\mathrm{H})^{+}$. ${ }^{1} \mathrm{H}-\mathrm{NMR}\left(300 \mathrm{MHz}, \mathrm{DMSO}-d_{6}\right) \delta: 12.12(\mathrm{~s}, 1 \mathrm{H}), 11.45(\mathrm{~s}$, $1 \mathrm{H}), 9.10(\mathrm{~s}, 1 \mathrm{H}), 9.08(\mathrm{~s}, 1 \mathrm{H}), 8.49(\mathrm{~s}, 1 \mathrm{H}), 7.86(\mathrm{~d}, J=8.6 \mathrm{~Hz}$, 2H), $7.72(\mathrm{~s}, 1 \mathrm{H}), 7.59(\mathrm{~d}, J=8.6 \mathrm{~Hz}, 2 \mathrm{H}), 7.44-7.39(\mathrm{~m}, 2 \mathrm{H})$, $7.33-7.30(\mathrm{~m}, 2 \mathrm{H}), 7.18(\mathrm{~s}, 1 \mathrm{H}), 6.96(\mathrm{~d}, J=7.7 \mathrm{~Hz}, 1 \mathrm{H}), 3.67$ (s, $2 \mathrm{H}), 3.32(\mathrm{~s}, 1 \mathrm{H}), 3.14(\mathrm{~s}, 2 \mathrm{H}), 2.56(\mathrm{~s}, 8 \mathrm{H}), 1.39(\mathrm{~s}, 9 \mathrm{H}), 1.27$ $(\mathrm{s}, 9 \mathrm{H})$

1-(4-(4-((4-(2-(2-(5-Benzyloxy-2-hydroxybenzylidene)hydrazinyl)-2-oxoethyl)piperazin-1-yl)methyl)thiazol-2-yl)phenyl)-3-phenylurea Dihydrochloride (1d): Yield 62.5\%. mp 202-204 ${ }^{\circ} \mathrm{C}$. ESI-MS m/z: $676.3(\mathrm{M}+\mathrm{H})^{+} .{ }^{1} \mathrm{H}-\mathrm{NMR}(300 \mathrm{MHz}$, DMSO- $\left.d_{6}\right) \delta$ : $11.94(\mathrm{~s}, 1 \mathrm{H}), 9.71(\mathrm{~d}, J=13.4 \mathrm{~Hz}, 1 \mathrm{H}), 9.42$ (d, $J=12.7 \mathrm{~Hz}, 1 \mathrm{H}), 8.32(\mathrm{~s}, 1 \mathrm{H}), 7.90(\mathrm{~s}, 4 \mathrm{H}), 7.63(\mathrm{~d}, J=8.1 \mathrm{~Hz}$, $3 \mathrm{H}), 7.49-7.38(\mathrm{~m}, 7 \mathrm{H}), 7.35-7.26(\mathrm{~m}, 4 \mathrm{H}), 6.99(\mathrm{~d}, J=7.1 \mathrm{~Hz}$, $2 \mathrm{H}), 6.87$ (d, J=8.8 Hz, 1H), 5.05 (s, 2H), 4.56 (s, 1H), 4.47 (s, $2 \mathrm{H}), 3.78$ (s, 1H), 3.59 (brs, $8 \mathrm{H})$.

1-(4-(4-((4-(2-(2-(5-Benzyloxy-2-hydroxybenzylidene)hydrazinyl)-2-oxoethyl)piperazin-1-yl)methyl)thiazol-2-yl)phenyl)-3(2-chloro-4-(trifluoromethyl)phenyl)urea Dihydrochloride (1e): Yield 52.3\%. mp $214-215^{\circ} \mathrm{C}$. ESI-MS $m / z$ : $778.4(\mathrm{M}+\mathrm{H})^{+}$. ${ }^{1} \mathrm{H}-\mathrm{NMR}\left(300 \mathrm{MHz}, \mathrm{DMSO}-d_{6}\right) \delta$ : $11.96(\mathrm{~s}, 1 \mathrm{H}), 10.62(\mathrm{~d}$, $J=14.0 \mathrm{~Hz}, 1 \mathrm{H}), 9.75$ (s, 1H), $9.02(\mathrm{~d}, J=7.0 \mathrm{~Hz}, 1 \mathrm{H}), 8.62$ $(\mathrm{s}, 1 \mathrm{H}), 8.51(\mathrm{~s}, 1 \mathrm{H}), 8.33(\mathrm{~s}, 1 \mathrm{H}), 7.96-7.93(\mathrm{~m}, 3 \mathrm{H}), 7.72$ (d, $J=8.2 \mathrm{~Hz}, 2 \mathrm{H}), 7.68$ (s, 1H), 7.44-7.32 (m, 7H), 6.99 (dd, $\left.J_{1}=2.8 \mathrm{~Hz}, J_{2}=8.9 \mathrm{~Hz}, 1 \mathrm{H}\right), 6.88(\mathrm{~d}, J=8.9 \mathrm{~Hz}, 1 \mathrm{H}), 5.05(\mathrm{~s}$, $2 \mathrm{H}), 4.58$ (s, 1H), 4.50 (s, 2H), 3.84 (s, 1H), 3.68 (brs, 8H).

1-(4-(4-((4-(2-(2-(5-Benzyloxy-2-hydroxybenzylidene)- 
hydrazinyl)-2-oxoethyl)piperazin-1-yl)methyl)thiazol-2-yl)phenyl)-3-(2-trifluoromethoxyphenyl)urea Dihydrochloride (1f): Yield 54.1\%. mp $225-226^{\circ} \mathrm{C}$. ESI-MS $\mathrm{m} / \mathrm{z}$ : 760.3 $(\mathrm{M}+\mathrm{H})^{+} .{ }^{1} \mathrm{H}-\mathrm{NMR}\left(300 \mathrm{MHz}, \mathrm{DMSO}-d_{6}\right) \delta: 11.98(\mathrm{~s}, 1 \mathrm{H})$, 10.06 (d, $J=11.7 \mathrm{~Hz}, 1 \mathrm{H}), 9.98$ (d, $J=10.9 \mathrm{~Hz}, 1 \mathrm{H}), 8.51$ (s, 1H), 8.34 (s, 1H), 7.96-7.91 (m, 4H), $7.71(\mathrm{~s}, 1 \mathrm{H}), 7.64$ (d, J=8.6 Hz, $1 \mathrm{H}), 7.46-7.31(\mathrm{~m}, 8 \mathrm{H}), 7.22(\mathrm{~d}, J=2.9 \mathrm{~Hz}, 1 \mathrm{H}), 7.01-6.87$ $(\mathrm{m}, 3 \mathrm{H}), 5.06(\mathrm{~s}, 2 \mathrm{H}), 4.62(\mathrm{~s}, 1 \mathrm{H}), 4.53(\mathrm{~s}, 2 \mathrm{H}), 3.94(\mathrm{~s}, 1 \mathrm{H})$, $3.72-3.51(\mathrm{~m}, 8 \mathrm{H})$.

1-(4-(4-((4-(2-(2-(5-Benzyloxy-2-hydroxybenzylidene)hydrazinyl)-2-oxoethyl)piperazin-1-yl)methyl)thiazol-2-yl)phenyl)-3-(2-trifluoromethylphenyl)urea Dihydrochloride (1g): Yield 53.7\%. mp $241-244^{\circ} \mathrm{C}$. ESI-MS $m / z$ : $744.4(\mathrm{M}+\mathrm{H})^{+}$. ${ }^{1} \mathrm{H}-\mathrm{NMR}\left(300 \mathrm{MHz}, \mathrm{DMSO}-d_{6}\right) \delta: 12.00(\mathrm{~s}, 1 \mathrm{H}), 10.14(\mathrm{~d}$, $J=11.9 \mathrm{~Hz}, 1 \mathrm{H}), 10.02$ (d, $J=10.1 \mathrm{~Hz}, 1 \mathrm{H}), 8.51$ (s, 1H), 8.34 (s, $1 \mathrm{H}), 8.02-7.92(\mathrm{~m}, 4 \mathrm{H}), 7.67(\mathrm{~s}, 1 \mathrm{H}), 7.63(\mathrm{~d}, J=8.7 \mathrm{~Hz}, 2 \mathrm{H})$, $7.53(\mathrm{t}, J=7.7 \mathrm{~Hz}, 1 \mathrm{H}), 7.44-7.30(\mathrm{~m}, 7 \mathrm{H}), 6.99\left(\mathrm{dd}, J_{1}=3.0 \mathrm{~Hz}\right.$, $\left.J_{2}=8.9 \mathrm{~Hz}, 1 \mathrm{H}\right), 6.89(\mathrm{~d}, J=8.8 \mathrm{~Hz}, 1 \mathrm{H}), 5.06(\mathrm{~s}, 2 \mathrm{H}), 4.64(\mathrm{~s}$, $1 \mathrm{H}), 4.56(\mathrm{~s}, 2 \mathrm{H}), 4.03(\mathrm{~s}, 1 \mathrm{H}), 3.75-3.58(\mathrm{~m}, 8 \mathrm{H})$.

1-(4-(4-((4-(2-(2-(4-Benzyloxy-2-hydroxybenzylidene)hydrazinyl)-2-oxoethyl)piperazin-1-yl)methyl)thiazol-2-yl)phenyl)-3-(3-chlorophenyl)urea Dihydrochloride (1h): Yield 54.1\%. mp 213-215 ${ }^{\circ} \mathrm{C}$. ESI-MS $m / z: 710.2(\mathrm{M}+\mathrm{H})^{+} .{ }^{1} \mathrm{H}-\mathrm{NMR}$ $\left(300 \mathrm{MHz}, \mathrm{DMSO}-d_{6}\right) \delta$ : $11.78(\mathrm{~s}, 1 \mathrm{H}), 9.65$ (d, $J=10.8 \mathrm{~Hz}$, $1 \mathrm{H}), 9.59$ (d, $J=12.4 \mathrm{~Hz}, 1 \mathrm{H}), 8.26(\mathrm{~s}, 1 \mathrm{H}), 7.91(\mathrm{~d}, J=8.7 \mathrm{~Hz}$, $2 \mathrm{H}), 7.86(\mathrm{~d}, J=9.0 \mathrm{~Hz}, 1 \mathrm{H}), 7.71(\mathrm{~s}, 1 \mathrm{H}), 7.66-7.61(\mathrm{~m}, 3 \mathrm{H})$, $7.45-7.40(\mathrm{~m}, 5 \mathrm{H}), 7.37-7.33(\mathrm{~m}, 2 \mathrm{H}), 7.31(\mathrm{~d}, J=5.2 \mathrm{~Hz}, 2 \mathrm{H})$, 7.04-7.02 (m, 1H), 6.57-6.55 (m, 2H), $5.12(\mathrm{~s}, 1 \mathrm{H}), 5.09(\mathrm{~s}$, $1 \mathrm{H}), 4.48$ (s, 1H), 4.43 (s, 2H), 3.46 (br s, 9H).

1-(4-(4-((4-(2-(2-(4-Benzyloxy-2-hydroxybenzylidene)hydrazinyl)-2-oxoethyl)piperazin-1-yl)methyl)thiazol-2-yl)phenyl)-3(3,4-dichlorophenyl)urea Dihydrochloride (1i): Yield 50.4\%. $\mathrm{mP} \quad 205-207^{\circ} \mathrm{C}$. ESI-MS $m / z: 744.1 \quad(\mathrm{M}+\mathrm{H})^{+} .{ }^{1} \mathrm{H}-\mathrm{NMR}$ $\left(300 \mathrm{MHz}, \mathrm{DMSO}-d_{6}\right) \delta: 11.77$ (s, 1H), 9.65 (brs, 2H), 8.25 $(\mathrm{s}, 1 \mathrm{H}), 7.93-7.88(\mathrm{~m}, 5 \mathrm{H}), 7.62(\mathrm{~d}, J=8.6 \mathrm{~Hz}, 3 \mathrm{H}), 7.53(\mathrm{~d}$, $J=8.8 \mathrm{~Hz}, 1 \mathrm{H}), 7.45-7.33(\mathrm{~m}, 6 \mathrm{H}), 6.61-6.54(\mathrm{~m}, 2 \mathrm{H}), 5.12$ (s, 1H), 5.09 (s, 1H), 4.43 (brs, 3H), 3.45 (brs, 9H).

2-(4-(2-(2-(2-Hydroxybenzylidene)hydrazinyl)-2-oxoethyl)piperazin-1-yl)- $N$-(4-(3-(3-(trifluoromethyl)phenyl)ureido)phenyl)acetamide Dihydrochloride (2a): Yield 45.1\%. mp 245-248 ${ }^{\circ}$ C. ESI-MS $m / z: 598.4(\mathrm{M}+\mathrm{H})^{+} .{ }^{1} \mathrm{H}-\mathrm{NMR}(300 \mathrm{MHz}$, DMSO- $\left.d_{6}\right) \delta: 11.98(\mathrm{~s}, 1 \mathrm{H}), 10.59(\mathrm{~s}, 1 \mathrm{H}), 10.17$ (s, 1H), 9.77 (s, $1 \mathrm{H}), 9.42(\mathrm{~s}, 1 \mathrm{H}), 8.39$ (s, $1 \mathrm{H}), 8.01(\mathrm{~s}, 1 \mathrm{H}), 7.71(\mathrm{~d}, J=6.5 \mathrm{~Hz}$, 1H), 7.58-7.53 (m, 4H), 7.50-7.43 (m, 3H), 7.33-7.25 (m, 2H), 6.97-6.85 (m, 2H), 4.59 (s, 1H), 4.04 (s, 2H), 3.86 (s, 1H), 3.54 (s, 8H).

2-(4-(2-(2-(3,5-Di-tert-butyl-2-hydroxybenzylidene)hydrazinyl)-2-oxoethyl)piperazin-1-yl)- $N$-(4-(3-(3-(trifluoromethyl)phenyl)ureido)phenyl)acetamide Dihydrochloride (2b): Yield 58.9\%. mp 275-277 ${ }^{\circ}$. ESI-MS $m / z: 710.3(\mathrm{M}+\mathrm{H})^{+} .{ }^{1} \mathrm{H}-\mathrm{NMR}$ $\left(300 \mathrm{MHz}, \mathrm{DMSO}-d_{6}\right) \delta: 11.99(\mathrm{~s}, 1 \mathrm{H}), 10.56(\mathrm{~s}, 1 \mathrm{H}), 9.66(\mathrm{~s}$, $1 \mathrm{H}), 9.32(\mathrm{~s}, 1 \mathrm{H}), 8.51(\mathrm{~s}, 1 \mathrm{H}), 8.00(\mathrm{~s}, 1 \mathrm{H}), 7.59-7.43(\mathrm{~m}, 6 \mathrm{H})$, 7.32-7.24 (m, 3H), $4.06(\mathrm{~s}, 4 \mathrm{H}), 3.82(\mathrm{~s}, 4 \mathrm{H}), 3.46$ (s, 6H), 1.40 (s, 9H), $1.28(\mathrm{~s}, 9 \mathrm{H})$.

$\mathrm{N}$-(4-(3-(3-Chlorophenyl)ureido)phenyl)-2-(4-(2-(2-(2hydroxybenzylidene)hydrazinyl)-2-oxoethyl)piperazin-1-yl)acetamide Dihydrochloride (2c): Yield 57.2\%. mp 259-261 ${ }^{\circ} \mathrm{C}$. ESI-MS $m / z: 564.2(\mathrm{M}+\mathrm{H})^{+} .{ }^{1} \mathrm{H}-\mathrm{NMR}\left(300 \mathrm{MHz}, \mathrm{DMSO}-d_{6}\right)$ $\delta: 11.43(\mathrm{~s}, 1 \mathrm{H}), 11.21(\mathrm{~s}, 1 \mathrm{H}), 9.60(\mathrm{~s}, 1 \mathrm{H}), 8.84(\mathrm{~s}, 1 \mathrm{H}), 8.68$ $(\mathrm{s}, 1 \mathrm{H}), 8.53(\mathrm{~s}, 1 \mathrm{H}), 7.71(\mathrm{~s}, 1 \mathrm{H}), 7.54(\mathrm{~d}, J=8.9 \mathrm{~Hz}, 2 \mathrm{H})$, $7.48\left(\mathrm{dd}, J_{1}=1.7 \mathrm{~Hz}, J_{2}=7.2 \mathrm{~Hz}, 1 \mathrm{H}\right), 7.38(\mathrm{~d}, J=8.9 \mathrm{~Hz}, 2 \mathrm{H})$, $7.32-7.23(\mathrm{~m}, 3 \mathrm{H}), 7.02-6.99(\mathrm{~m}, 1 \mathrm{H}), 6.93-6.88(\mathrm{~m}, 2 \mathrm{H}), 3.33$ $(\mathrm{s}, 1 \mathrm{H}), 3.14(\mathrm{~s}, 1 \mathrm{H}), 3.12(\mathrm{~s}, 2 \mathrm{H}), 2.59(\mathrm{~s}, 8 \mathrm{H})$.

$\mathrm{N}$-(4-(3-(4-Chloro-3-(trifluoromethyl)phenyl)ureido)phenyl)-2-(4-(2-(2-(2-hydroxybenzylidene)hydrazinyl)-2oxoethyl)piperazin-1-yl)acetamide Dihydrochloride (2d): Yield 51.4\%. mp 260-261 ${ }^{\circ} \mathrm{C}$. ESI-MS $m / z$ : $632.1(\mathrm{M}+\mathrm{H})^{+} .{ }^{1} \mathrm{H}-\mathrm{NMR}$ $\left(300 \mathrm{MHz}, \mathrm{DMSO}-d_{6}\right) \delta$ : $11.99(\mathrm{~s}, 1 \mathrm{H}), 10.69(\mathrm{~s}, 1 \mathrm{H}), 10.06$ (s, $1 \mathrm{H}), 9.53(\mathrm{~s}, 1 \mathrm{H}), 8.40(\mathrm{~s}, 1 \mathrm{H}), 8.11(\mathrm{~s}, 1 \mathrm{H}), 7.77(\mathrm{~d}, J=7.3 \mathrm{~Hz}$, $1 \mathrm{H}), 7.65-7.56(\mathrm{~m}, 5 \mathrm{H}), 7.45(\mathrm{~d}, J=8.9 \mathrm{~Hz}, 2 \mathrm{H}), 7.33-7.24(\mathrm{~m}$, $1 \mathrm{H}), 6.98-6.93(\mathrm{~m}, 1 \mathrm{H}), 6.91-6.85(\mathrm{~m}, 1 \mathrm{H}), 4.62(\mathrm{~s}, 1 \mathrm{H}), 4.12$ (s, 2H), 3.95 (s, 1H), 3.64 (brs, 8H).

$2-(4-(2-(2-(5-(B e n z y l o x y)-2-h y d r o x y b e n z y l i d e n e)-$ hydrazinyl)-2-oxoethyl)piperazin-1-yl)-N-(4-(3-(3(trifluoromethyl)phenyl)ureido)phenyl)acetamide Dihydrochloride (2e): Yield 58.3\%. mp $210-212^{\circ} \mathrm{C}$. ESI-MS $\mathrm{m} / \mathrm{z}$ : 704.3 $(\mathrm{M}+\mathrm{H})^{+} .{ }^{1} \mathrm{H}-\mathrm{NMR}\left(300 \mathrm{MHz}, \mathrm{DMSO}-d_{6}\right) \delta$ : $11.40(\mathrm{~s}, 1 \mathrm{H})$, 10.65 (s, 1H), 9.58 (s, 1H), 8.99 (s, 1H), 8.71 (s, 1H), 8.48 (s, $1 \mathrm{H}), 8.01(\mathrm{~s}, 1 \mathrm{H}), 7.55-7.50(\mathrm{~m}, 4 \mathrm{H}), 7.47-7.28(\mathrm{~m}, 9 \mathrm{H}), 7.15$ $(\mathrm{d}, J=2.9 \mathrm{~Hz}, 1 \mathrm{H}), 6.98\left(\mathrm{dd}, J_{1}=3.0 \mathrm{~Hz}, J_{2}=8.9 \mathrm{~Hz}, 1 \mathrm{H}\right), 6.84$ (d, $J=8.8 \mathrm{~Hz}, 1 \mathrm{H}), 5.05$ (s, 2H), 3.30 (s, 1H), 3.12 (s, 3H), 2.59 (s, $8 \mathrm{H})$.

2-(4-(2-(2-(5-(Benzyloxy)-2-hydroxybenzylidene)hydrazinyl)-2-oxoethyl)piperazin-1-yl)- $N$-(4-(3-(3-chlorophenyl)ureido)phenyl)acetamide Dihydrochloride (2f): Yield 53.1\%. mp 203-205 ${ }^{\circ} \mathrm{C}$. ESI-MS $m / z: 670.4 \quad(\mathrm{M}+\mathrm{H})^{+} .{ }^{1} \mathrm{H}-\mathrm{NMR}$ $\left(300 \mathrm{MHz}, \mathrm{DMSO}-d_{6}\right) \delta$ : $11.40(\mathrm{~s}, 1 \mathrm{H}), 10.65(\mathrm{~s}, 1 \mathrm{H}), 9.58$ $(\mathrm{s}, 1 \mathrm{H}), 8.99(\mathrm{~s}, 1 \mathrm{H}), 8.71(\mathrm{~s}, 1 \mathrm{H}), 8.48(\mathrm{~s}, 1 \mathrm{H}), 8.01(\mathrm{~s}, 1 \mathrm{H})$, $7.55-7.50(\mathrm{~m}, 4 \mathrm{H}), 7.47-7.28(\mathrm{~m}, 9 \mathrm{H}), 7.15(\mathrm{~d}, J=2.9 \mathrm{~Hz}, 1 \mathrm{H})$, $6.98\left(\mathrm{dd}, J_{1}=3.0 \mathrm{~Hz}, J_{2}=8.9 \mathrm{~Hz}, 1 \mathrm{H}\right), 6.84(\mathrm{~d}, J=8.8 \mathrm{~Hz}, 1 \mathrm{H})$, $5.05(\mathrm{~s}, 2 \mathrm{H}), 3.30(\mathrm{~s}, 1 \mathrm{H}), 3.12(\mathrm{~s}, 3 \mathrm{H}), 2.59(\mathrm{~s}, 8 \mathrm{H})$.

2-(4-(2-(2-(5-(Benzyloxy)-2-hydroxybenzylidene)hydrazinyl)-2-oxoethyl)piperazin-1-yl)- $N$-(4-(3-(4-chloro-3-(trifluoromethyl)phenyl)ureido)phenyl)acetamide Dihydrochloride (2g): Yield 47.8\%. mp $180-182^{\circ} \mathrm{C}$. ESI-MS $\mathrm{m} / \mathrm{z}: 738.4$ $(\mathrm{M}+\mathrm{H})^{+} .{ }^{1} \mathrm{H}-\mathrm{NMR}\left(300 \mathrm{MHz}, \mathrm{DMSO}-d_{6}\right) \delta: 11.43(\mathrm{~s}, 1 \mathrm{H})$, $10.66(\mathrm{~s}, 1 \mathrm{H}), 9.60(\mathrm{~s}, 1 \mathrm{H}), 9.11(\mathrm{~s}, 1 \mathrm{H}), 8.77$ (s, 1H), 8.48 (s, $1 \mathrm{H}), 8.11(\mathrm{~s}, 1 \mathrm{H}), 7.61-7.54(\mathrm{~m}, 4 \mathrm{H}), 7.46-7.32(\mathrm{~m}, 7 \mathrm{H}), 7.15$ $(\mathrm{d}, J=2.9 \mathrm{~Hz}, 1 \mathrm{H}), 6.98\left(\mathrm{dd}, J_{1}=2.9 \mathrm{~Hz}, J_{2}=8.8 \mathrm{~Hz}, 1 \mathrm{H}\right), 6.84$ $(\mathrm{d}, J=8.8 \mathrm{~Hz}, 1 \mathrm{H}), 5.05(\mathrm{~s}, 2 \mathrm{H}), 3.32(\mathrm{~s}, 1 \mathrm{H}), 3.12(\mathrm{~s}, 3 \mathrm{H}), 2.58$ (s, 8H).

2-(4-(2-(2-((7-Hydroxy-4-methyl-2-oxo-2H-chromen-6-yl)methylene)hydrazinyl)-2-oxoethyl)piperazin-1-yl)- $N$-(4-(3-(3(trifluoromethyl)phenyl)ureido)phenyl)acetamide Dihydrochloride (2h): Yield 54.2\%. mp 261-263 ${ }^{\circ} \mathrm{C}$. ESI-MS $\mathrm{m} / \mathrm{z}: 680.3$ $(\mathrm{M}+\mathrm{H})^{+} .{ }^{1} \mathrm{H}-\mathrm{NMR}\left(300 \mathrm{MHz}, \mathrm{DMSO}-d_{6}\right) \delta: 12.53(\mathrm{~s}, 1 \mathrm{H})$, $10.64(\mathrm{~s}, 1 \mathrm{H}), 9.71(\mathrm{~d}, J=9.0 \mathrm{~Hz}, 1 \mathrm{H}), 9.39(\mathrm{~d}, J=7.4 \mathrm{~Hz}, 1 \mathrm{H})$, $9.36(\mathrm{~s}, 1 \mathrm{H}), 9.01(\mathrm{~s}, 1 \mathrm{H}), 8.00(\mathrm{~s}, 1 \mathrm{H}), 7.75(\mathrm{~d}, J=8.9 \mathrm{~Hz}, 1 \mathrm{H})$, $7.59-7.50(\mathrm{~m}, 4 \mathrm{H}), 7.45(\mathrm{~d}, J=8.9 \mathrm{~Hz}, 2 \mathrm{H}), 7.29(\mathrm{~d}, J=7.4 \mathrm{~Hz}$, $1 \mathrm{H}), 6.97$ (d, J=8.9 Hz, 1H), $6.28(\mathrm{~s}, 1 \mathrm{H}), 4.52(\mathrm{~s}, 1 \mathrm{H}), 4.12$ (s, $2 \mathrm{H}), 3.77$ (s, 1H), 3.55-3.27 (m, 8H), 2.42 (s, 3H).

$N$-(4-(3-(3-Chloro-4-(trifluoromethyl)phenyl)ureido)phenyl)-2-(4-(2-(2-((7-hydroxy-4-methyl-2-oxo-2H-chromen-6yl)methylene)hydrazinyl)-2-oxoethyl)piperazin-1-yl)acetamide Dihydrochloride (2i): Yield 49.0\%. mp 249-251 ${ }^{\circ} \mathrm{C}$. ESI-MS $m / z: 714.0 \quad(\mathrm{M}+\mathrm{H})^{+} .{ }^{1} \mathrm{H}-\mathrm{NMR} \quad\left(300 \mathrm{MHz}, \quad \mathrm{DMSO}-d_{6}\right) \quad \delta$ : 12.47 (s, 1H), $10.61(\mathrm{~s}, 1 \mathrm{H}), 9.85(\mathrm{~d}, J=8.9 \mathrm{~Hz}, 1 \mathrm{H}), 9.37$ (d, $J=6.1 \mathrm{~Hz}, 1 \mathrm{H}), 9.01(\mathrm{~s}, 1 \mathrm{H}), 8.63(\mathrm{~s}, 1 \mathrm{H}), 8.11$ (s, 1H), 7.74 (d, $J=8.9 \mathrm{~Hz}, 1 \mathrm{H}), 7.61(\mathrm{~s}, 2 \mathrm{H}), 7.55(\mathrm{~d}, J=8.9 \mathrm{~Hz}, 2 \mathrm{H}), 7.44$ (d, $J=8.9 \mathrm{~Hz}, 2 \mathrm{H}), 6.97(\mathrm{~d}, J=8.9 \mathrm{~Hz}, 1 \mathrm{H}), 6.27$ (s, 1H), 4.49 (s, $1 \mathrm{H}), 4.10$ (s, 2H), 3.74 (s, 1H), 3.52-3.24 (m, 8H), 2.42 (s, 3H).

Cytotoxicity The cytotoxicity of compounds $\mathbf{1 a}-\mathbf{i}$ and 
2a-i were evaluated against A549, MDA-MB-231 and HL-60 cell lines, and $\mathbf{1 a}, \mathbf{1 f}$ and $\mathbf{1 h}$ were evaluated against WI38 cell line by the MTT method in vitro, with sorafenib and PAC-1 as the positive controls. The cancer cell lines and the normal cell line were cultured in minimum essential medium (MEM) supplement with $10 \%$ fetal bovine serum (FBS).

Approximately $4 \times 10^{3}$ cells, suspend in MEM medium, were plated onto each well of a 96 -well plate and incubated in $5 \%$ $\mathrm{CO}_{2}$ at $37^{\circ} \mathrm{C}$ for $24 \mathrm{~h}$. The tested compounds at indicated final concentrations were added to the culture medium and the cell cultures were continued for $72 \mathrm{~h}$. Fresh MTT was added to each well at a terminal concentration of $5 \mu \mathrm{g} / \mathrm{mL}$ and incubated with cells at $37^{\circ} \mathrm{C}$ for $4 \mathrm{~h}$. The formazan crystals were dissolved in $100 \mu \mathrm{L}$ dimethyl sulfoxide (DMSO) per well, and the absorbency at $492 \mathrm{~nm}$ (for absorbance of MTT formazan) and $630 \mathrm{~nm}$ (for the reference wavelength) was measured with the enzyme-linked immunosorbent assay (ELISA) reader. All of the compounds were tested twice in the cell lines. The results expressed as $\mathrm{IC}_{50}$ (inhibitory concentration of 50\%) were the averages of two determinations and were calculated by using the Bacus Laboratories Inc. Slide Scanner (Bliss) software.

Acknowledgements This work was supported by the National High Technology Research and Development Program ("863" Program) of China (No. 2012AA020305) and National Natural Science Foundation of China (No. 21002065 and No. 81102470).

\section{References}

1) Lai C. J., Bao R., Tao X., Wang J., Atoyan R., Qu H., Wang D. G., Yin L., Samson M., Forrester J., Zifcak B., Xu G. X., DellaRocca S., Zhai H. X., Cai X., Munger W. E., Keegan M., Pepicelli C. V., Qian C., Cancer Res., 70, 3647-3656 (2010).
2) Traxler P., Allegrini P. R., Brandt R., Brueggen J., Cozens R., Fabbro D., Grosios K., Lane H. A., McSheehy P., Mestan J., Meyer T., Tang C., Wartmann M., Wood J., Caravatti G., Cancer Res., 64, 4931-4941 (2004).

3) Motzer R. J., Michaelson M. D., Redman B. G., Hudes G. R., Wilding G., Figlin R. A., Ginsberg M. S., Kim S. T., Baum C. M., DePrimo S. E., Li J. Z., Bello C. L., Theuer C. P., George D. J., Rini B. I., J. Clin. Oncol., 24, 16-24 (2006).

4) Dai C. L., Tiwari A. K., Wu C. P., Su X. D., Wang S. R., Liu D. G., Ashby C. R. Jr., Huang Y., Robey R. W., Liang Y. J., Chen L. M., Shi C. J., Ambudkar S. V., Chen Z. S., Fu L. W., Cancer Res., 68, 7905-7914 (2008).

5) Rini B. I., Expert Opin. Pharmacother., 7, 453-461 (2006).

6) Tamaskar I., Bukowski R., Elson P., Ioachimescu A. G., Wood L., Dreicer R., Mekhail T., Garcia J., Rini B. I., Ann. Oncol., 19, 265-268 (2008).

7) Wilhelm S. M., Adnane L., Newell P., Villanueva A., Llovet J. M., Lynch M., Mol. Cancer Ther., 7, 3129-3140 (2008).

8) Wilhelm S. M., Carter C., Tang L. Y., Wilkie D., McNabola A., Rong H., Chen C., Zhang X., Vincent P., McHugh M., Cao Y., Shujath J., Gawlak S., Eveleigh D., Rowley B., Liu L., Adnane L., Lynch M., Auclair D., Taylor I., Gedrich R., Voznesensky A., Riedl B., Post L. E., Bollag G., Trail P. A., Cancer Res., 64, 7099-7109 (2004).

9) Adnane L., Trail P. A., Taylor I., Wilhelm S. M., Methods Enzymol., 407, 597-612 (2006).

10) Wilhelm S., Carter C., Lynch M., Lowinger T., Dumas J., Smith R. A., Schwartz B., Simantov R., Kelley S., Nat. Rev. Drug Discov., 5, 835-844 (2006).

11) Kelley R. K., Venook A. P., J. Clin. Oncol., 26, 5845-5848 (2008).

12) Peterson Q. P., Hsu D. C., Goode D. R., Novotny C. J., Totten R. K., Hergenrother P. J., J. Med. Chem., 52, 5721-5731 (2009).

13) Putt K. S., Chen G. W., Pearson J. M., Sandhorst J. S., Hoagland M. S., Kwon J. T., Hwang S. K., Jin H., Churchwell M. I., Cho M. H., Doerge D. R., Helferich W. G., Hergenrother P. J., Nat. Chem. Biol., 2, 543-550 (2006). 